\title{
Başkent Üniversitesi Ankara Hastanesi Acil Servisine Başvuran Adli Nitelikteki Çocuk Olguların Değerlendirilmesi
}

\author{
Assesment of Forensic Children Cases Applying to the Emergency Service of Başkent \\ University Ankara Hospital
}

Erhan Büken, Zehtiye Füsun Yaşar

Başkent Üniversitesi Tip Fakültesi Adli Tip Anabilim Dalı, Ankara

\section{Özet}

Amaç: Bu çalışma, Başkent Üniversitesi Ankara Hastanesi Acil Servisine başvuran 0-18 yaş grubundaki adli olguların demografik özelliklerini, başvuru nedenlerini ve hazırlanan adli raporların niteliklerini belirlemek, elde edilen verileri benzer çalışmalarla karşılaştırmak amacıyla yapılmıştır.

Gereç ve Yöntem: Tanımlayıcı nitelikteki bu araştırmanın örneklemini, Başkent Üniversitesi Ankara Hastanesi Acil Servisinde 01/01/2013-31/12/2013 tarihleri arasında hazırlanan 2397 adli bildirim raporu oluşturmaktadır. Çalışma, bu raporların çocuklara ait 664'ünün değerlendirmesini içermektedir.

Bulgular: Çocuk Acil Servisimize başvuran 0-18 yaşındaki çocuklara ait olgular, tüm adli raporların \%27,70'sini oluşturmaktadır. Çocukların 316’sı (\%45,0) kız, 348’i (\%49,5) erkektir. Olguların en fazla olduğu yaş $402(\% 50,54)$ ile $0-6$ yaş grubu çocuklardır. Olay tipinin cinsiyet ayrımı yapılmaksızın dağılımına baktı̆̆ımızda en sık yanık olayları (n:218, \%32,83) nedeniyle acil servislere başvurulduğu, bu değeri sırasıyla; zehirlenmeler (n: 119, \%17,92), düşme (n: 77, \%11,60), trafik kazaları (n: 70, \%10,54) ve yabancı cisim aspirasyonu (n: 63, $\% 9,49)$ olgularının izlediği görülmektedir. Olay tipleri cinsiyet ayrımı yapılarak değerlendirildiğinde yanıkların kızlarda \%39,55, erkeklerde ise $\% 27,87$ değeriyle yine ilk sırada yer aldığı görülmektedir.

Sonuç: Çocukluk çă̆ındaki önlenebilir sağlık sorunlarının önemli bir kısmını kazalar oluşturmaktadır. Bu kazalar sonucu oluşan ve adli nitelik taşıyan yaralanmalar çoğunlukla ev kazaları sonucunda oluşmaktadır. Çocuk kazalarının önlenebilmesi için yaşam alanlarında gerekli güvenlik tedbirlerinin alınması kaza riskleriniz azaltılmasında etkin bir yöntem olarak görülmektedir.

Anahtar kelimeler: Adli olgu, Çocuk, Kaza, Tedbir.

\begin{abstract}
Objective: This study has been carried out in order to determine the demographic properties, application reasons and qualifications of the legal reports prepared of the forensic cases in the group of 0-18 ages that applies to the Emergency Service of Başkent University Ankara Hospital and to compare the data obtained with similar studies.
\end{abstract}

Materials and Methods: Sample of this study which has a descriptive characteristic is compose of 2397 forensic notification reports prepared between the dates of 01/01/2013-31/12/2013 in the Emergency Service of Başkent University Ankara Hospital. The study includes the evaluation of 664 reports of the children.

Results: The cases of children between 0-18 years who applied to Children Emergency Service constitute 27,70\% of all forensic reports. $316(45,0 \%)$ of the children are girls and $348(49,5 \%)$ are boys. The highest rate of the cases is seen in 0-6 year group with 402 (50,54\%) children. When we look at the distribution of the type of the case regardless the gender, it is observed that the emergency services are applied for burn cases at most (n:218, 32,83\%) and this is respectively followed by the poisoning (n: 119, 17,92\%), falling down (n: 77, 11,60\%), traffic accidents (n: 70, 10,54\%) and swallowing foreign object (n: 63, 9,49\%) cases. When the type of the cases are assessed considering the gender, it is seen that burn comes first in the girls with $39,55 \%$ and in boys with $27,87 \%$.

Conclusion: Accidents constitute a major part of the preventable health problems in childhood. The injuries that occur as a result of such accidents and have a forensic characteristic happen generally in consequence of home accidents. In order to prevent the children accidents, taking necessary security measures in the living spaces is seen as an effective method to decrease the risks of accident.

Keywords: Forensic case, Child, Accident, Precaution.

\section{Giriș}

Acil servislerine; darp, trafik kazası, her türlü alet yaralanmaları, yanık, düşme, asfiksi, kötü muamele, intihar girişimleri vb nedenlerle başvuran olgular adli olgu olarak değerlendirilir (1,2). Hastane acil servisine başvuran olguların büyük bir çoğunluğu adli olgu niteliğindedir. Türk Ceza Kanunu'nun (TCK) 279. ve 280. maddelerine göre adli

Sorumlu Yazar: Uzm. Zehtiye Füsun Yaşar

Başkent Üniversitesi Tip Fakültesi Adli Tip Anabilim Dalı, Ankara

E-mail: zehtiye2004@gmail.com olguların sağlık çalışanı tarafından adli makamlara bildiriminin yapılması gereklidir (3). Birleşmiş Milletler Genel Kurulu tarafından 1986 yılında kabul edilen ve Ülkemizde 1995 yılında yürürlüğe giren Çocuk Haklarına Dair Sözleşme'sinin 1. Maddesine göre, istisnalar hariç (çocuğa uygulanabilecek kanuna göre daha erken yaşta reşit olma durumu), 18 yaşına kadar her insan çocuk kabul edilir. Sözleşmenin 9. maddesinin 1. bendi göre; yetkili makamlar, çocuğun, ana-babası tarafından kötü muameleye maruz kalması veya ihmal edilmesi durumunda, ebeveynin rızası olmaksızın bir ayrılık kararı 
verebilir ve çocuğu koruma altına alabilir (4). Alınan bu koruma tedbirlerine rağmen çocukluk çağında önlenebilir nedenlerle oluşan çocuk kazalarının oranı hala yüksektir. Adli olgu olarak nitelenen bu tip kazalarda ilk başvuru yeri acil servisler olduğundan, çocuk ihmal ve istismarının önlenebilmesi verilerin doğru düzenlenmesiyle sağlanabilir.

$\mathrm{Bu}$ çalışma ile çocukların yaşam alanlarını güvenliğinin sağlanmasının gerekliliğine ilişkin veriler toplayıp, acil servise başvuran ve adli nitelik taşıyan 0-18 yaş grubu hastaların demografik ve klinik özelliklerinin ortaya konması yanı sıra hazırlanan adli bildirim raporlarının değerlendirilmesi amaçlanmıştır.

\section{Gereç ve Yöntem}

Başkent Üniversitesi Tıp Fakültesi Ankara Hastanesi Acil Servisinde 2013 yılında 0-18 yaş arasındaki hastalara ait 664 adli bildirim raporu retrospektif olarak incelenmiştir. Olgular; yaş, cinsiyet, olayın oluş yeri, olay tipi, olay zamanı, yaralanmanın tipi ve lokalizasyonu gibi özellikleri açısından değerlendirilmiştir. Olguların yaşları; 0-6 yaş (okul öncesi), 712 yaş (okul çağ 1 ) ve 13-18 yaş (adölesan) grubu olarak sınıflandırılmıştır. Verilerin analizinde SPSS paket programinda (Version 17.0, Chicago IL, USA) gerçekleştirilmiş, verilerin değerlendirilmesinde frekans dağılımları belirlenmiş ve Pearson $\chi 2$ testi kullanılmıştır. Bu çalışma Başkent Üniversitesi Tıp ve Sağlık Araştırma Kurulu tarafından onaylanmış (Proje no:KA14/49, Proje ismi: Başkent Üniversitesi Üniversitesi Hastanesi Acil Servisinde 2013 yılında hazırlanan adli raporların değerlendirilmesi) ve Başkent Üniversitesi Araştırma fonunca desteklenmiştir.

\section{Bulgular}

Başkent Üniversitesi Tıp Fakültesi Ankara Hastanesi Acil Servisinde 2013 yılında 2397 adli bildirim raporu hazırlanmıştır. Bu raporların 664'ü $(\% 27,70)$ 0-18 yaşındaki çocuklara aittir. Çocukların 316'sı (\%45,0) kız, 348'I (\%49,5) erkektir Tablo 1). Yaralanmaların en fazla olduğu yaş 402

Tablo 1. Olguların yaş ve cinsiyetlerine göre dağılımı.

\begin{tabular}{lcccccc}
\hline \multicolumn{1}{c}{ Yaș } & \multicolumn{2}{c}{ Kız } & \multicolumn{2}{c}{ Erkek } & \multicolumn{2}{c}{ Toplam } \\
& $\mathbf{n}$ & $\%$ & $\mathbf{n}$ & $\%$ & $\mathbf{n}$ & $\%$ \\
0-6 yaș & 204 & 64,56 & 198 & 56,90 & 402 & 60,54 \\
7-12 yaş & 53 & 16,77 & 73 & 20,98 & 126 & 18,98 \\
13-18 yaș & 49 & 15,51 & 67 & 19,25 & 116 & 17,47 \\
Yașı belirsiz & 10 & 3,16 & 10 & 2,87 & 20 & 3,01 \\
TOPLAM & 316 & 100 & 348 & 100 & 664 & 100 \\
\hline
\end{tabular}

(\%50,54) 0-6yaş grubu çocuklardır.

Olguların oluş mekânlarına bakıldı̆̆ında ise 184 olguda $(\% 27,71)$ olay mekanının belirtilmediği 261'inin $(\% 30,31)$ evde, 119'unun $(\% 17,92)$ diş mekanda, 47'sinin $(\% 23,04)$ okulda gerçekleştiği belirlendi. Trafik kazası nedeniyle başvuran 70 çocuk olgusunun 38 ’inin $(\% 54,28)$ araç içinde (AİTK) olduğu saptand. Kazaların en fazla olduğu yaş 402 ile $(\% 50,54)$ 0-6 yaş grubu çocuklardır. Olguların mevsimlere göre dağılımına baktığımızda kazaların en fazla (n:190, \%28,61) ilkbahar mevsiminde olduğu belirlendi (Tablo 2).

Tablo 2. Olguların mevsimlere göre dağılımı.

\begin{tabular}{lcc}
\hline Mevsim & n & \% \\
\hline İlkbahar & 190 & 28,61 \\
Kiş & 157 & 23,65 \\
Sonbahar & 161 & 24,25 \\
Yaz & 156 & 23,49 \\
Toplam & 664 & 100 \\
\hline
\end{tabular}

Tablo 3. Olguların olay tipine ve cinsiyete göre dağılımı.

\begin{tabular}{lllllll}
\hline \multirow{2}{*}{ Olgu tipi } & \multicolumn{3}{l}{ Koz çocuk } & \multicolumn{2}{l}{ Erkek çocuk } & \multicolumn{2}{l}{ Toplam } \\
\cline { 2 - 7 } & $\boldsymbol{n}$ & $\boldsymbol{\%}$ & $\boldsymbol{n}$ & $\boldsymbol{\%}$ & $\boldsymbol{n}$ & $\boldsymbol{\%}$ \\
\hline Yanık & 121 & $\mathbf{3 8 , 2 9}$ & 97 & $\mathbf{2 7 , 8 7}$ & 218 & $\mathbf{3 2 , 8 3}$ \\
Zehirlenme & 59 & $\mathbf{1 8 , 6 7}$ & 60 & $\mathbf{1 7 , 2 4}$ & 119 & $\mathbf{1 7 , 9 2}$ \\
Yabanc1 cisim yutma & 31 & 9,81 & 32 & 9,20 & 63 & 9,49 \\
Yüksekten düșme & 33 & 10,44 & 44 & 12,64 & 77 & $\mathbf{1 1 , 6 0}$ \\
Nedeni belirtilmemiș travmalar & 24 & 7,59 & 48 & 13,79 & 72 & 10,84 \\
Trafik kazasi & 35 & $\mathbf{1 1 , 0 8}$ & 35 & 10,06 & 70 & $\mathbf{1 0 , 5 4}$ \\
Özkiyim girişimi & 7 & 2,22 & 2 & 0,58 & 9 & 1,36 \\
Darp & 6 & 1,90 & 29 & 8,33 & 35 & 5,27 \\
Cinsel istismar & 0 & 0 & 1 & 0,29 & 1 & 0,15 \\
Toplam & 316 & 100 & 348 & 100 & 664 & 100 \\
\hline
\end{tabular}

${ }^{*}$ Adli bildirim raporlarnda olay tipi belirtilmemiş travmalar, nedeni belirtilmemis travmalar başlı̆̆ altında toplanmıştır.

${ }^{*}$ Zehirlenme: besin, ilaç, korozif madde, CO zehirlenmesidir. 
Olguların olay tipine göre dağılımına bakıldığında; en fazla (n:218, \%32,83) yanık nedeniyle hastaların acil servise başvurduğunu, bunu sirasıyla (n: 119, \%17,92) ile zehirlenme ve (n: 77, \%11,60) ile yüksekten düşme olgularının takip ettiği görülmektedir (Tablo 3). Yapılan $\mathrm{x}^{2}$ testinde $\mathrm{p}=0,00$ değeriyle olgu tipleriyle cinsiyet arasında anlamlı bir fark olduğu belirlendi. Tablo 3'deki zehirlenme başlığı altında; CO, ilaç, besin ve diğer zehirlenmeler değerlendirilmiş olup diğer zehirlenmeler grubunda ebeveynleri tarafından sıvı temizlik maddeleri (Korozif maddeler) içtiği şüphesiyle acil servise getirilen çocuk olgular ifade edilmektedir. Zehirlenme nedeniyle başvuran 119 olgunun 56'sını $(\% 47,06)$ diğer zehirlenme, 38'ini $(\% 31,93)$ ilaç, 17'sini $(\% 14,29)$ CO ve 8'ini $(\% 6,72)$ besin zehirlenmesi oluşturmaktadır. Darp olgularının (n:35) 15’i $(\% 42,86)$ darp, 20’si $(\% 57,14)$ ise arkadaş kavgasıdır.

Olay tipinin yaşa göre dağılımına baktığımız; 0-6 yaş grubunda en sık görülen olay tipi $159(\% 34,55)$ ile yanıktır. 718 yaş grubunda ise $47(\% 19,42)$ ile trafik kazasıdır (tablo 4$)$. Çalışmaya alınan çocuklarda olgu tipleri ile yaş arasındaki ilişki karşılaştırıldığında, aralarındaki fark istatistiksel olarak anlamlı bulundu $(\mathrm{p}=0.00)$.

Tablo 4. Çocuklarda olgu tiplerinin yaşa göre dağılımı.

\begin{tabular}{|c|c|c|c|c|c|c|c|c|}
\hline \multirow{3}{*}{ Olay tip } & \multicolumn{8}{|c|}{ Yaş } \\
\hline & \multicolumn{2}{|c|}{$0-6$ yaș } & \multicolumn{2}{|c|}{ 7-12 yaș } & \multicolumn{2}{|c|}{ 13-18 yaș } & \multicolumn{2}{|c|}{ Toplam } \\
\hline & $\mathbf{n}$ & $\%$ & $\mathbf{n}$ & $\%$ & $\mathbf{n}$ & $\%$ & $\mathbf{n}$ & $\%$ \\
\hline Yanık & 159 & 39,55 & 28 & 22,22 & 16 & 13,79 & 203 & 31,52 \\
\hline Zehirlenme & 88 & 21,9 & 17 & 13,49 & 14 & 12,07 & 119 & 18,47 \\
\hline Yabanc1 cisim yutma & 56 & 13,93 & 5 & 3,97 & 1 & 0,86 & 62 & 9,63 \\
\hline Yüksekten düșme & 54 & 13,43 & 18 & 14,29 & 5 & 4,31 & 77 & 11,96 \\
\hline Nedeni belirtilmemiș travmalar & 22 & 5,47 & 19 & 15,08 & 29 & 25,00 & 70 & 10,87 \\
\hline Trafik kazası & 21 & 5,22 & 25 & 19,84 & 22 & 18,97 & 68 & 10,56 \\
\hline Özkıyım girişımi & 0 & 0 & 0 & 0 & 9 & 7,76 & 9 & 1,4 \\
\hline Darp & 2 & 0,5 & 13 & 10,32 & 20 & 17,24 & 35 & 5,43 \\
\hline Cinsel istismar & 0 & 0 & 1 & 0,79 & 0 & 0 & 1 & 0,16 \\
\hline Toplam & 402 & 100 & 126 & 100 & 116 & 100 & 644 & 100 \\
\hline
\end{tabular}

*Yaşı belirsiz 20 (10 kız, 10 erkek) olgu dahil edilmediğinden 664 olan sayı tablo 4'de 644 olarak görülmektedir.

Olay tipleri cinsiyete ve yaşa göre dağılımına baktığımızda; 0-6 yaş grubu kız ve erkekler çocuklarda, yanıklar olgularının kızlarda $n=88, \% 43,14$, erkeklerde $n=71, \% 35,86$ ) değeriyle ilk sırada, zehirlenmelerin ise kızlara $\mathrm{n}=43, \% 21,07$ ve erkeklerde $\mathrm{n}=45, \% 22,73$ ile yine her iki cinsiyette ve bu yaş grubunda birbirine yakın değerde ikinci sırada yer aldığı görülmektedir. Yaş ilerledikçe kız ve erkek çocukların maruz kaldığı olay tiplerinde farklilıklar gözlenmektedir. 13-18 yaş grubunda nedeni belirtilmemiş travmalar erkeklerde $(n=21, \% 31,34)$ iken kızlarda $(n=8, \% 16,32)$, darp olguları ise erkeklerde $(n=17$, $\% 25,37)$ kızlarda ise $(\mathrm{n}=3, \% 6,32)$ olarak görülmektedir (Tablo $5,6)$. Bu sonuç ileri yaşlarda kız ve erkek çocukların maruz kaldığı olay tipi arasında anlamlı bir farklılık olduğunu ( $\mathrm{p}=$ $0.00)$ göstermektedir.

Tablo 5. Kız çocuklarda olgu tiplerinin yaşa göre dağılımı.

\begin{tabular}{lcccccccc}
\hline \multirow{2}{*}{ Olgu tipi } & \multicolumn{2}{c}{$\mathbf{0 - 6}$ yaş } & \multicolumn{2}{c}{$\mathbf{7 - 1 2}$ yaş } & \multicolumn{2}{c}{$\mathbf{1 3 - 1 8}$ yaş } & \multicolumn{2}{c}{ Toplam } \\
\cline { 2 - 9 } & $\mathbf{n}$ & $\mathbf{\%}$ & $\mathbf{n}$ & $\mathbf{\%}$ & $\mathbf{n}$ & $\mathbf{\%}$ & $\mathbf{n}$ & $\mathbf{\%}$ \\
\hline Yanık & $\mathbf{8 8}$ & 43,14 & 17 & 32,08 & 7 & 14,29 & 112 & 36,6 \\
Zehirlenme & $\mathbf{4 3}$ & 21,07 & 8 & 15,1 & 8 & 16,33 & 59 & 19,28 \\
Yabancı cisim yutma & 28 & 13,73 & 2 & 3,77 & 1 & 2,04 & 31 & 10,13 \\
Yüksekten düşme & 26 & 12,75 & 5 & 9,43 & 2 & 4,08 & 33 & 10,78 \\
Nedeni belirtilmemiş travmalar & 9 & 4,41 & 6 & 11,32 & 8 & $\mathbf{1 6 , 3 2}$ & 23 & 7,52 \\
Trafik kazası & 10 & 4,9 & 12 & 22,64 & 13 & 26,53 & 35 & 11,44 \\
Özkıyım girişimi & 0 & 0 & 0 & 0 & 7 & 14,29 & 7 & 2,29 \\
Darp & 0 & 0 & 3 & 5,66 & 3 & $\mathbf{6 , 1 2}$ & 6 & 1,96 \\
Toplam & 204 & 100 & 53 & 100 & 49 & 100 & 306 & 100 \\
\hline
\end{tabular}

${ }^{*}$ Yaşı belirsiz 10 çocuk tabloda yer almamaktadır. 
Tablo 6. Erkek çocuklarda olgu tiplerinin yaşa göre dağılımı.

\begin{tabular}{lcccccccc}
\hline \multirow{2}{*}{ Olgu tipi } & \multicolumn{3}{c}{$\mathbf{0 - 6}$ yaş } & \multicolumn{2}{c}{$\mathbf{7 - 1 2}$ yaş } & \multicolumn{2}{c}{$\mathbf{1 3 - 1 8}$ yas } & \multicolumn{2}{c}{ Toplam } \\
\cline { 2 - 10 } & $\mathbf{n}$ & $\%$ & $\mathbf{n}$ & $\%$ & $\mathbf{n}$ & $\%$ & $\mathbf{n}$ & $\%$ \\
\hline Yanık & 71 & 35,86 & 11 & 15,07 & 9 & 13,43 & 97 & 27,87 \\
Zehirlenme & 45 & 22,73 & 9 & 12,33 & 6 & 8,96 & 60 & 17,24 \\
Yabancı cisim yutma & 28 & 14,14 & 3 & 4,11 & 0 & 0 & 32 & 9,2 \\
Yüksekten düşme & 28 & 14,14 & 13 & 17,81 & 3 & 4,48 & 44 & 12,64 \\
Nedeni belirtilmemiş travmalar & 13 & 6,57 & 13 & 17,81 & 21 & $\mathbf{3 1 , 3 4}$ & 48 & 13,8 \\
Trafik kazası & 11 & 5,56 & 13 & 17,81 & 9 & 13,43 & 35 & 10,06 \\
Özkııım girişimi & 0 & 0 & 0 & 0 & 2 & 2,99 & 2 & 0,57 \\
Darp & 2 & 1,01 & 10 & 13,7 & 17 & $\mathbf{2 5 , 3 7}$ & 29 & 8,33 \\
Cinsel istismar & 0 & 0 & 1 & 1,36 & 0 & 0 & 1 & 0,29 \\
Toplam & 198 & 100 & 73 & 100 & 67 & 100 & 348 & 100 \\
\hline
\end{tabular}

*Yaşı belirsiz 10 çocuk tabloda yer almamaktadır.

Değerlendirilen 664 olguya ait adli bildirim raporunun 170’inde (\%25,60) lezyon bulgusu, 269'unda (\%40,51) lezyon tipi, 228'inde $(\% 34,34)$ lezyon lokalizasyonu ve ise ile ilgili veri kaydının olmadığı belirlenmiştir. Lezyon lokalizasyonu kaydedilen 436'sında $(\% 65,66)$ olguda, lezyon bulgularının 137'si (\%31,42) baş-boyun, 118'si $(\% 27,06)$ üst ekstremite, 84'ü $(\% 19,27)$ alt ekstremite, 50'si $(\% 11,47)$ multipl bölge, 21’i $(\% 4,82)$ göğüste diğer kısmı ise $(\% 2,30)$ sırt-bel, $(\% 1,14)$ batın ve $(\% 2,52)$ genital bölgede lokalizedir (Grafik 1).

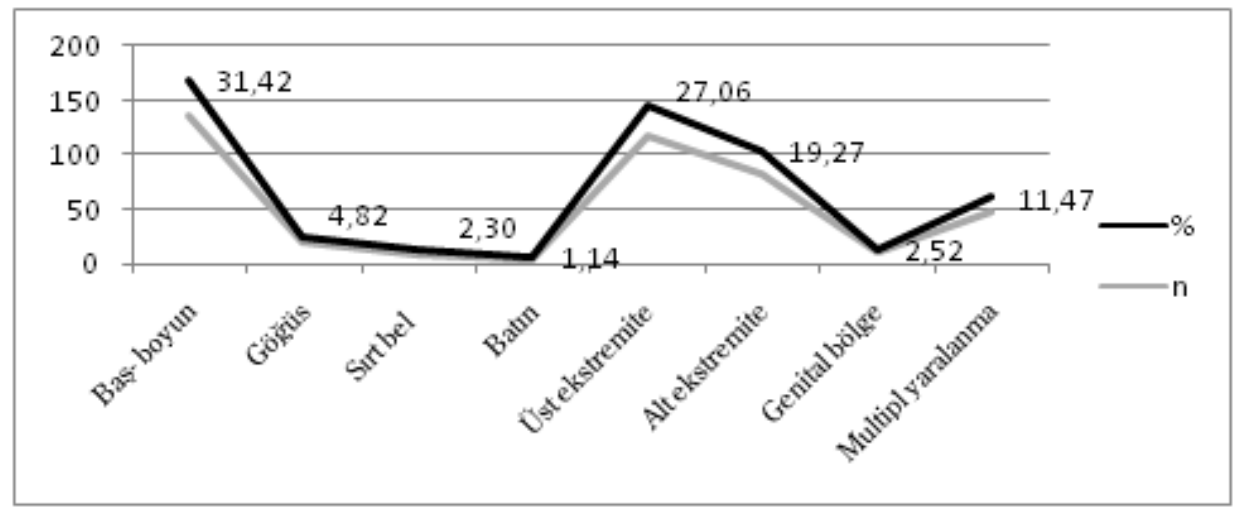

Grafik 1. Lezyon bulgularının lokalizasyonu.

Düzenlenen adli bildirim raporlarının 23’ünde $(\% 3,46)$ sonuç detayı belirtilmemiş, olguların basit tıbbi tedavi ile giderilip giderilemeyeceği ise sadece 1 raporda belirtilmiştir. Raporlarda 535 olguda $(\% 80,57)$ yaşamsal tehlikenin olmadığı, 46 olguda ise $(\% 6,92)$ yaşamsal tehlikenin olduğu kayıtlıdır. Hazırlanan adli bildirim raporlarının 183'ünde $(\% 27,56)$ rapor özelliği kayıtlı olmayıp, 391'inin $(\% 58,88)$ geçici, 90’ının kesin rapor olduğu bilgisi yer almaktadır.

\section{Tartışma}

Ülkemizde acil serviste adli olgular üzerinde yapılan çalışmalarda sadece çocuk grubun değerlendirildiği bir çalışma sayısı yetersizdir. Tüm adli olgular arasında çocuk hastaların yaklaşık oranı farklı çalışmalarda $\% 43, \% 28, \% 26, \% 24$, \%22 ve \%18 olarak bildirilmiştir (5-10). Çalışmamızda çocuk olguların tüm adli olgulara oranı $\% 27,7$ olarak saptanmış ve literatür bilgileriyle uyumlu bulunmuştur. Çocukların cinsiyete göre dağılımına baktı̆̆ımızda erkek/kız oranının $(\% 52,40 / \% 47,59)$ birbirine yakın değerde olduğu belirlenmiştir. $\mathrm{Bu}$ sonuç 0-18 yaş gurubu çocukların aktif yaşamlarının benzerliği ile ilişkilendirilmektedir.

Dicle Üniversitesi Tıp Fakültesi Acil Servis ve Yanık Ünitesinde 739 hasta üzerinde $\mathrm{Al}$ ve ark. tarafından yapılan çalışmada yanık vakalarının 508'inin $(\% 68,74)$ 0-6 yaş gurubu çocuklarda olduğu belirlenmiştir (11). Benzer şekilde Sarıtaş ve ark.'nın çalışmasında da olay tipi, hastaların yaşları gruplara göre incelendiğinde yanık vakalarının en fazla $(\% 46,7) 10$ yaş altında görüldüğ̈u ve bunların çoğunun haşlanma tipi yanık olduğu belirlenmiştir (12). Bizim çalışmamızda da 0-18 yaş grubundaki toplam 203 yanık olgusunun, 159'unun $(\% 78,33)$ 0- 
6 yaş grubunda olduğu belirlenmiştir. Çalışma sonucumuz bu değerin daha yüksek olması Üniversitemiz Hastanesinde Yanık Servisi olmasıyla açıklanabilir.

Çocuk Acil Kliniğine zehirlenme nedeniyle başvuran olguların 119 (\%17,92) olduğu belirlenmiştir. Çalışmamızda zehirlenmelerin oluş nedenleri; $\mathrm{CO}$, ilaç, besin ve diğer zehirlenmeler olarak dört başlık altında değerlendirilmiştir. Diğer zehirlenmeler grubunda ebeveynleri tarafından sıvı temizlik maddeleri (Korozif maddeler) içtiği şüphesiyle acil servise getirilen çocuk olgular ifade edilmektedir. Zehirlenme nedeniyle başvuran 119 olgunun 56'sını (\%47,06) diğer zehirlenme, 38'ini (\%31,93) ilaç, 17'sini $(\% 14,29)$ CO ve 8'ini $(\% 6,72)$ besin zehirlenmesi oluşturmaktadır. Zehirlenme olgularının oranı Polat ve ark.'nın çalışmasında olguların \%4.0'ünün, Erzurum'da Orbak ve ark. tarafından yapılan çalışmasında \%3,1, Tunç ve ark.'nın çalışmasında \%3,4, Kahveci ve ark.'nın 2004 çalışmasında ise \%2,2 olarak belirlenmiştir (13, 14, 15, 16). Çalışmamızda çocuklarda zehirlenme olgularının literatürlerden çok farklı olması, çalışmanın büyük şehirde yapılmış olması, çocukların günlük yaşamlarının çoğunu kreş ve okulda geçirmeleri veya bakıcı gözetiminde olması ve eğitim seviyesi yüksek ebeveynlerin en küçük şüphe durumunda bile acile başvurmalarıla açıklanabilir. Bu özelliğin yanı sıra 0-6 yaş grubunda kimyasal madde ve ilaç zehirlenme vaka sayısının fazla olması, ailelerin bu tip maddeleri yaşam alanlarında uygun koşullarda saklamadıklarını, çocukların ulaşabileceği yerlerde bırakma alışkanlıklarının olduğunu düşündürmektedir.

Karateke ve ark. yaptığı çalışmada 0-6 yaş grubunda en sık karşılaşılan kaza türü, düşme olup tüm ev kazalarının \%67,21'sini oluşturmaktadır (17). Yücel ve ark.'nın çalışmasında da 0-59 ay arası çocuklarda düşme sonucu yaralanma olayı oranının \%32,2 olduğu belirlenmiştir (18). Konuyla ilgili yapılan çalışmalarda da benzer şekilde en sık karşılaşılan ev kazası tipinin düşme olduğunu göstermektedir $(19,20,21)$. Çalışmamızda düşmeye bağlı çocuk yaralanmaları $0-18$ yaş grubunda $77(\% 11,96)$ iken vakaların 54'ünün $(\% 70,13)$ 0-6 yaş grubunda olduğu belirlendi.

Bilgin ve ark.'nın yaptığı çalışmada trafik kazaları \%32 ile ikinci sırada, Çınar ve ark.'nın yaptığı çalışmada ise $\% 52$ ile ilk sırada yer alırken bizim çalışmamızda trafik kazaları ( $n=70$ $\% 10,54)$ ile dördüncü sırada yer almaktadır $(6,10)$. Çalışmamızda trafik kazalarının \%48,57'si araç içi, \%51,43’ü araç dışı trafik kazası şeklindedir. Trafik kazası mağdurlarının \%30,88 'inin 0-6 yaş grubu olduğu belirlenmiştir. Bu sonuç, çocukların araç içinde uygun koşullarda seyahati için ebeveynler tarafından gerekli tedbirlerin alınmadığını ve çocuklara yaya olarak uymaları gereken trafik kurallar konusunda yeterince eğitim verilmediğini düşündürmektedir.
Yabancı cisim aspirasyonu her yaşta görülebilse de 3 yaş altında \%73 gibi yüksek bir değerdedir (22). Bu oran Gürsel ve arkadaşlarının çalışmasında \%84, Apa ve ark.'nın çalışmasında \%86 olarak bulunmuştur $(23,24)$. Turla ve ark.'nın çalışmasında da yabancı cisim aspirasyonu 0-6 yaş gurubunda \%77,1 değerindedir (2). Çalışmamızda da toplam 62 yabancı cisim aspirasyonu vakasının 56'sının (\%90,32) 0-6 yaş grubu çocuklarda olduğu belirlenmiştir ki bu sonuç literatürle uyumludur. Yabancı cisim aspirasyonu vakalarının bu kadar yüksek değerde olması bu yaş grubundaki çocukların nesneleri ağızla tanımlama isteklerinden ve ebeveynlerin tedbirsizliğinden kaynaklandığı düşünülmektedir.

Gerek çalışmamızın gerek se, yaptı̆̆ımız literatür çalışmasının sonuçları, çocukluk çağında oluşan ve adli nitelik taşıyan yaralanmaların azımsanmayacak sayıda olduğunu göstermektedir. Çocukluk çağı yaralanmalarının çoğu evde gerçekleşen, önlenebilir ve engellenebilir niteliktedir, bu nedenle, aile ve toplum düzeyinde alınacak tedbirlerle çocuklar için güvenli yaşam alanlarının oluşturulması gereklidir. Çocukluk çağı yaralanmaların oluşumunu engellemek için; ilaç ve korozif maddelerin ve makas- bıçak gibi kesici delici aletlerin çocukların ulaşamayacağı yerlerde saklanması, sıcak içeceklerin çocuğun eline verilmemesi veya ebeveyn kontrolünde verilmesi vb. tedbirlerin alınması kaza risklerinin azaltılmasında katkı sağlayacaktır.

Acil servislerde bu tip vakalarda hazırlanacak olan adli bildirim raporlarının, eksiksiz doldurulması çocuk ihmal ve istismarının belirlenmesi açısından önemlidir. Ancak çalışmamızda değerlendirilen 664 olguya ait adli bildirim raporunun 170'inde $(\% 25,60)$ lezyon bulgusu, 269'unda $(\% 40,51)$ lezyon tipi, 228 ’inde $(\% 34,34)$ lezyon lokalizasyonu ve 183 ’ünde $(\% 27,56)$ rapor özelliğgi ile ilgili veri kaydının olmadığ 1 belirlenmiştir. Adli olguların raporlarının özenli ve doğru hazırlanması için acil tıp uzmanlarının adli tıp uzmanları ile koordineli çalışmanın uygun olacağ

\section{Teşekkür}

Projenin gerçekleştirilmesinde, Başkent Üniversitesi Tıp Fakültesi 2013-2014 Eğitim Dönemi, Dönem III öğrencilerinden; Güzide Ece Akıncı, Elif Şahin, Irmak Şimşek, Güngör Çakmakçı ve Ayşe Ece Şener'e dosya taramasına katkıları nedeniyle teşekkür ederiz.

\section{Kaynaklar}

1. Durak D. Acil serviste adli problemler. 1. Ulusal Acil Servis Hekimliği Kongresi, 02-04 Nisan 2004: Bursa. Özet Kitabı: 35-8.

2. Turla A, Aydın B. Ondokuz Mayıs Üniversitesi Tıp Fakültesine başvuran adli nitelikteki çocuk olguların değerlendirilmesi. Adli Tip Bülteni 2007;12(3):106-111).

3. TCK, CMK, CGTIK ve ilgili mevzuat. 7.baskı. Ankara: Adalet Yayınevi, 2005:372-3.

4. Çocuk Haklarına Dair Sözleşme. Resmi Gazete, 27 Ocak 1995, Say1: 22184:4-15. 
5. Demircan A, Keleş A, Gürbüz N, Bildik F, AygencelŞG, Doğan NÖ et al. Forensic emergency medicine - six-year experience of 13823 cases in a university emergency department. Turkish Journal of Medical Sciences 2008;38(6):567-575

6. Bilgin NG, Canbaz H, Mert E. Characteristics of forensic cases admitted to the emergency department of the Mersin University Hospital. Turkish Journal of Forensic Sciences 2004; 3 (4):37-44.

7. Altun G, Azmak D, Yilmaz A, Yilmaz G. The characteristics of the cases which admitted to emergency department of Trakya Üniversity Medical Faculty. Bulletin of Legal Medicine 1997; 2(2):62-6.

8. Aydin B, Turla A, Dündar C. A study on the cases of incised and stab woundings reported between 1997-2002 in Samsun. Turkish Journal of Forensic Sciences 2004; 3 (3): 7-13.

9. Cantürk G, Eșiyok B, Polat O, Korkusuz İ, Akduman B. Evaluation of intoxication cases applied to Emergency Department of Ankara University Hospital in 2002. Turkish Journal of Forensic Sciences 2005; 4 (1):39-45.

10. Çınar O, Acar YA, Çevik E, Kılıç E, Bilgiç S, Ak M, Cömert B. Acil servise başvuran 0-18 yaş grubu adli olguların özellikleri (Analysis of forensic cases in the $0-18$ years age group that were presented to emergency department). Anatol J Clin Investig 2010; 4(3):148-151.

11. Al B, Güllü MN, Okur H, Öztürk H, Kara İH, Aldemir M. Doğu Anadolu ve Güneydoğu Anadolu Bölgelerinde Haşlanma ve Alev Yanıklarının Epidemiyolojik Özellikleri. Tıp Araştırmaları Dergisi 2005; (3-1): 14-21.

12. Sarıtaş A, Çıkman M, Çandar M, Kandiş H, Baltacı D. Kliniğimize başvuran adli nitelikteki yanık vakalarının geriye dönük analizi: 4 yıllık tecrübe. Düzce Tip Dergisi 2011; 13(3): 2933.

13. Polat S, Özyazıcıŏlu N, Tüfekci FG, Yazar F. Çocuk acil kliniğine başvuran 0-18 yaş grubu olguların incelenmesi, Atatürk Üniv. Hemşirelik Yüksekokulu Dergisi2005; 8(2): 55-62.
14. Orbak Z, Selimoğlu A, Alp H. Erzurum bölgesinde çocuklarda zehirlenme olgularının değerlendirilmesi. Çocuk Sağlığı ve Hastalıkları Dergisi 1996; 39: 497-504.

15. Tunç B, Örmeci AR, Dolgun A ve ark. Isparta bölgesinde çocukluk çağı zehirlenme nedenleri. Çocuk Sağlığı ve Hastalıkları Dergisi 1995; 38: 211-212.

16. Kahveci M, Çeltik C, Karasalihoğlu S ve ark. Bir üniversite hastanesi acil servisine başvuran çocukluk çağ 1 zehirlen Başkent Üniversitesi melerinin değerlendirilmesi. Step 2004; 13(1):19-21.

17. Karatepe TU, Akıs N N. 0-6 Yaş Cocuklarda Ev Kazası Geçirme Sıklığı ve İlişkili Faktörler. Uludağ Üniversitesi Tıp Fakültesi Dergisi 2013;39 (3) 165-168.

18. Yücel A B, Sütoluk Z, Yılmaz L H, Akbaba M, Aytaç N, Çukurova Üniversitesi Tip Fakültesi Çocuk Acil Servisi'ne 2004 yılında başvuran ve adli vaka olarak kayıtlara geçen olguların değerlendirilmesi, Adli Tıp Bülteni 2005;10(3):90-95.

19. Kılıç B, Demiral Y. İzmir'de bir gecekondu bölgesinde evde yaralanma insidansı. Toplum Hekimliği Bülteni 2006; 25 (3):27-32.

20. Alptekin F, Uskun E, Kisioglu AN, Ozturk M. Unintentional nonfatal home-related injuries in Central Anatolia, Turkey: frequencies, characteristics, and outcomes. Injury 2008 May; 39(5):535-46.

21. Morrongiello BA, Ondejko L, Littlejohn A. Understanding Toddlers' In-Home Injuries: I. Context, Correlates, and Determinants. Journal of Pediatric Psychology 2004; 29 (6): 415-431.

22. Senkaya I, Sagdıç K, Gebitekin C,Yılmaz M, Özkan H, Cengiz M. Management of foreign body aspiration in infancy and childhood. Turk J Ped 1997; 39:353-62.

23. Gürses D, Akçay A, Çakalar I, Kılıs I, Ergin H, Kara C. Çocukluk çağı yabancı cisim aspirasyonlarının degerlendirilmesi. Çocuk Dergisi 2004; 4:98-101.

24. Apa H, Kayserili E, Hızarcıoglu M, Gülez P, Umaç Ö, Diniz A G. Çocukluk çağı yabancı cisim aspirasyonları. ADÜ Tıp Fakültesi Dergisi 2005; 6(3): 17-21. 